\title{
The Effect of Internal Control Material Weaknesses on Future Stock Price Crash Risk: Evidence from Tehran Stock Exchange (TSE)
}

\section{Seyed Mohammad Reza Razavi Araghi ${ }^{1 *}$ and Zahra Lashgari²}

${ }^{1}$ Bank Supervision Department, Central Tehran Branch, Master's in Accounting in Islamic Azad University, Iran

${ }^{2}$ Assistant Professor and Faculty Member, Islamic Azad University, Central Tehran Branch, Iran

\begin{abstract}
Internal controls are methods put in place by a company to ensure the integrity of financial and accounting information, meet operational and profitability targets, and transmit management policies throughout the organization. Since 2012, attention to internal control in Iran became more serious; indicating its importance in entity's activities. Given that investors tend to be concerned about returns and stock price crashes, the results of this study can be helpful for users of financial statements. Regarding the objective, this is an applied research using a correlational method. This study investigates the effect of internal control deficiencies on future stock price crash risk. A sample of 133 companies listed on Tehran Stock Exchange in the period 2011-2015 was selected and analyzed using a systematic elimination method. Logistic regression model was used for hypothesis testing. The research findings suggested that material weaknesses in internal control have positive and significant impacts on future stock price crash risk.
\end{abstract}

Keywords: Internal controls; Future stock price crash risk; SarbanesOxley Act

\section{Introduction}

According to the internal control guidelines adopted by Tehran Stock Exchange (TSE) in 2012, in order to achieve corporate objectives, the board of directors is required to ensure that internal controls are established and implemented appropriately and effectively, and at least annually, disclose the results in a report entitled "Reports on internal controls". That is why the topic was the focus of professional associations and experts in the field of accounting. According to the above mentioned definitions, empirical research on the issue is more essential than ever. Weaknesses in internal control can either directly or indirectly affect an entity's activities. Therefore, this study examines whether internal control weaknesses can affect stock price crash risk.

Internal control is a dynamic system covering all kinds of risks and deviations from policies and procedures Chorafas [1]. Chenhall [2] believes that internal controls are adopted to assist management to achieve business goals and desired results. Ogneva et al. [3] believe that internal control is a fundamental and dynamic process that continuously conforms to the changes that their organizations are faced with Karagiorgos et al. [4] believe that internal control is not just a one-sided tool for controlling the order and rightness of certain situations, but it is a method of detecting the value added up to a company, achieving the index of effectiveness and profitability of the company. Internal control systems reduce risks and help management in ensuring the reliability of financial statements and compliance with laws and regulations Spira and Page [5]. A weak control environment has the potential to allow error in estimation and procedures, earning's management by opportunistic managers and their tendency to withhold bad news due to various incentives Kothari et al. [6].

Corporate managers tend to exaggerate their financial performance by withholding bad news and accelerating the release of good news, hoping that poor current performance will be camouflaged by strong future performance. If managers withhold and camouflage bad news for an extended period, negative information is likely to be stockpiled within a company. Once the amount of accumulated bad news reaches a certain threshold and concealing them for a longer period is more costly or impossible, it will be released all at once, leading to negative stock returns following to shareholders' concern and thus stock price crashes Kim and Zhang [7]. The main question is whether the lack of effective internal control or a material weakness in internal control over financial reporting affects the major sources of information that is financial statements provided by corporations for capital market participants so that it leads to future stock price crash risk.

According to Hutton et al. [8] and Kim and Zhang [7] stock price crash implies that a corporate's stock price has suffered a sharp decline in the year under review. As the severe reductions in stock price can be the result of a general decline in market prices, the overall situation in the market should also be noted and the sharp reduction in stock return compared to the returns of the market should be defined. The stock price crash in the above-mentioned studies was defined as a qualitative variable that equals one for a firm-year that experiences atleast one crash month during the fiscal year period, and zero otherwise.

\section{Literature Review}

Lee et al. [9] in a study on the effect of internal control weakness on investment efficiency found that firms with internal accounting control weakness tend to make over and under-investment. They also found that internal accounting control weakness is negatively associated with investment efficiency.

Lashgari et al. [10] studied the relation between internal control weakness and accruals quality using data obtained from 200 companies

*Corresponding author: Seyed Mohammad Reza Razavi Araghi, Master's in Accounting in Islamic Azad University, Central Tehran Branch, Bank Examiner Bank Supervision Department, Central Bank of the Islamic Republic of Iran Tehran, Iran, Tel: +982122 565149; E-mail: mrrazavi514@gmail.com

Received February 02, 2017; Accepted April 10, 2017; Published April 14, 2017

Citation: Araghi SMRR, Lashgari Z (2017) The Effect of Internal Control Material Weaknesses on Future Stock Price Crash Risk: Evidence from Tehran Stock Exchange (TSE). Int J Account Res 5: 151. doi:10.4172/2472-114X.1000151

Copyright: (c) 2017 Araghi SMRR, et al. This is an open-access article distributed under the terms of the Creative Commons Attribution License, which permits unrestricted use, distribution, and reproduction in any medium, provided the original author and source are credited. 
listed on Tehran stock exchange between 2008 and 2013. Findings of their study showed that accruals quality is very strongly associate with the internal control weakness and indeed, quality of accounting information (accruals) is highly dependent on both providing information environment and information resources.

Zhou et al. [11] conducted a study on the material weaknesses in internal control and future stock price crash risk based on the evidence obtained under Section 404 of Sarbanes-Oxley Act (SOX). They selected a sample of 19397 companies in the period 2004-2011 and found that corporate with material weaknesses in internal control are more crashprone than companies with effective internal control. Findings of their study also suggest that corporate managers with material weaknesses in internal control tend to withhold bad news, and this increases the likelihood of stock price crash risk.

Cheng et al. [12] studied the relationship between earnings opacity, cash flows and stock price crash risk in 255 companies, during the period 2004-2010. Findings of their study showed that earnings opacity and operating cash flows sensitivity result in the lack of revealing bad news, and this increases the risk of stock price crash

\section{Research methodology}

In terms of objective, this is an applied research using a correlational method. The present study is considered a descriptive accounting research. At 95\% confidence level, the information needed for evaluating and testing the research hypotheses was obtained from financial statements and reports submitted to Tehran Stock Exchange, Rahavard Novin software, Codal site, and companies financial information CD. Excel (2010) and Eviews7 were used to perform the calculation, data preparation, and analysis.

After performing the steps outlined, descriptive statistics was used to describe the data. The Kolmogorov-Smirnov test was used to determine the parametric or nonparametric statistical methods. Spearman's rank correlation coefficient and Augmented Dickey-Fuller test (ADF) were used to determine the correlation coefficient between variables and the stationary research variables, respectively. Logistic Regression is used to test the research hypothesis. In other words, logistic regression, also called a logit model, is used when there are dummy variables, particularly when there are some qualitative variables. In addition to solving problems such as heterogeneity of variance and abnormality, the Logit model measures the estimated probability between 0 and 1 , and the results are logically satisfying and interesting.

\section{Developing hypothesis}

Given the above-mentioned definitions, the research hypothesis is as follows:

Material weaknesses in internal control affect the future stock price crash risk.

\section{Population and sampling method}

The research population consists of the companies listed on Tehran Stock Exchange during the period 2011-2015. The study used a systematic elimination sampling method to select samples and eliminate the companies that do not meet the following conditions:

- In order to comply with the comparability of the companies, the fiscal year end is March 31.

- The fiscal year cannot be changed during the research period.

- They should not belong in the categories of banks, insurers, and financial institutions (Investment companies, financial intermediaries, holding and leasing companies).

Ultimately, by applying the above requirements, the population consists of 133 companies listed on Tehran Stock Exchange.

\section{Models and variables}

Hypothesis testing was conducted using the following model developed by Ogneva et al. [3]. The control variables of the previous studies of GeWelli and McVay [13] and Ashbaugh-Skaife et al. [14] as the factors affecting material weakness in internal control were documented and entered in the model:

$\operatorname{Prob}($ WEAKi $)=\beta_{0+} \beta_{1}$ RESTRUCTURE $_{\mathrm{i}, \mathrm{t}}+\beta_{2}$ SALEGRW $_{\mathrm{i}, \mathrm{t}}+\beta_{3}$ INVEN

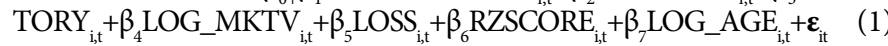

It should be noted that before testing the hypothesis, the effect of all variables, in the left side of the model, on the weaknesses of internal controls was tested and proven in an alternative hypothesis.

The variables in the model are described as follows:

Prob (Weak): Index that is equal to one if the company has material weakness in internal control, otherwise it is equal to zero. Since 2013 companies were required to report their internal controls. Therefore, the study used items mentioned in companies audit reports on material weaknesses in internal controls.

Restructure: Index that is equal to one if the company has restructured the organization in that period, otherwise it is equal to zero.

Salegrw: Index that is equal to one if the sale is below the average industry sales, otherwise it is equal to zero.

Inventory: Total inventories over total assets.

Log_MKTV: Logarithm of the market value of equity. (Price per share multiplied by the number of shares issued at the end of the period).

Loss: Index that is equal to one if earnings before items of emergency show loss, otherwise it is equal to zero.

Rzscore: Altman (1986) bankruptcy index in which a higher level of index indicates weakness and a higher probability of failure.

Log_age: Logarithm of the number of years that the Company has been listed on the Stock Exchange (It is assumed that older firms have better internal controls).

The dependent variable in this hypothesis was stock price crash risk, which was measured by Hutton et al. (2009) criterion:

$R_{j, \theta=} \alpha_{j+} \beta_{1 j} r_{m^{\prime} \theta-2}+\beta_{2 j} r_{m^{\prime} \theta-1+} \beta_{3 j} r_{m^{\prime} \theta}+\beta_{4 j} r_{m^{\prime} \theta+1+} \beta_{5 j} r_{m^{\prime} \theta+2+} \varepsilon_{j \theta}$

In this relation:

$r_{j \theta}$ : Monthly stock returns during the period $\theta$.

$\mathrm{R}_{\mathrm{m}, \theta}:$ Monthly market returns for month $\theta$. To calculate monthly market return, subtract the starting price index from the ending price index; then, divide the index's change by the starting price.

Following Hutton et al. [8] to calculate stock price crash risk, first the model should be tested for each year-company and then the residual or the firm-specific monthly stock return $\left(\mathrm{W}_{\mathrm{i}, \theta}\right)$ should be calculated using the following formula. We include "crash months" as those in which a firm experiences firm-specific monthly returns 3.2 
Citation: Araghi SMRR, Lashgari Z (2017) The Effect of Internal Control Material Weaknesses on Future Stock Price Crash Risk: Evidence from Tehran Stock Exchange (TSE). Int J Account Res 5: 151. doi:10.4172/2472-114X.1000151

Page 3 of 5

standard deviations below the mean firm-specific monthly returns over the entire fiscal year. Thus, when the obtained amount of (W) in a fiscal year is 3.2 standard deviations below, it means that stock price crash has taken place in that period. In this case, the CRASH variable is equal to one; otherwise it is equal to zero.

$$
\mathrm{W}_{\mathrm{i}, \theta}=\mathrm{LN}(1+\varepsilon)
$$

The effect of internal control weakness on stock price crash risk based on the proposed model of Zhou et al. [11] is tested as follows:

Crash Risk $\mathrm{t}_{\mathrm{t}} \mathrm{a}+$ Crash Risk Determinants $_{\mathrm{t}-1+}$ ICW Determinants $\mathrm{t}_{\mathrm{t}-1+} \varepsilon_{\mathrm{t}-1}$

In this relation:

Crash Risk: Stock price crash risk in t period as a dependent variable.

Crash Risk Determinants $_{\mathrm{t}-1}$ : Determinants of (Variables) future stock price crash risk in the previous year.

ICW Determinants t-1 $_{\text {: }}$ Determinants of (Variables) internal control weaknesses in the previous year.

Finally, following the models proposed by Ogneva et al. [3] and Zhou Jie et al. [11], the impact of factors affecting the internal control material weaknesses and other control variables on future stock price crash risk are estimated in maximum likelihood regression-binary logistic model:

Crash Risk $_{\mathrm{it}}=\beta_{0}+\beta_{1}$ CHASHRISK $_{\mathrm{it}-1}+\beta_{2}$ WEAK $_{\mathrm{it}-1}+\beta_{3}$ RESTRUCTURE $_{i, t}$

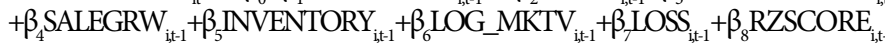
${ }_{1}+\beta_{9} L_{-}$OG_AGE ${ }_{i, t,-1}+\beta_{10} \mathrm{RET}_{\mathrm{i},-1-1}+\beta_{11} \mathrm{SIZE}_{\mathrm{i}, \mathrm{t}-1}+\beta_{12} \mathrm{LEV}_{\mathrm{i}, \mathrm{t}-1}+\beta_{13} \mathrm{ROA}_{\mathrm{i}, \mathrm{t},-1}+\beta_{14}$ OPAQUE i,t-1 $+\varepsilon_{\mathrm{it}-1}$

\section{In this relation:}

The control variables that influence future stock price crash risk and were used in the above model, are as follows:

RET: Average monthly return which is calculated as bellow:

$$
\operatorname{RET}_{\mathrm{j}, \mathrm{t}=} \sum_{\theta=1}^{\theta=12} r_{j}, \theta / N
$$

SIZE: Natural log of total net sales at the end of fiscal year.

LEV: Long-termdebt to total asset ratio

ROA: The ratio of net income to the average total asset at the end of company's fiscal year.
OPAQUE: Opacity of financial statements (Discretionary accruals obtained from modified-Jones model).

\section{Research Findings}

\section{Descriptive statistics}

Descriptive statistics for each variable for the selected 665 firm-year is as follows (Table 1):

\section{Data normality test}

The first step of the hypothesis testing process is the assessment of the normality of data. Kolmogorov-Smirnov test was used to test the hypothesis, the results of which are as follows:

The results of Kolmogorov-Smirnov test indicated that the firm all variables follow a lognormal distribution, while the rest of the variables follow a skewed distribution. Given that the dependent variable (Future stock price crash risk) is not normally distributed (Because it is qualitative, and the qualitative variables 0 and 1 are not normal); therefore, nonparametric methods are used for these variables (Table 2).

\section{Correlation between variables}

Spearman's rank correlation coefficient was used to determine the correlation between quantitative variables, the results of which are shown in Table 3.

\section{Unit root test (stationarity) variables}

An augmented Dickey-Fuller test (ADF) was used to test for stationarity, the results of which are shown in Table 4. The results of Table 4 indicated that all research variables with a $99 \%$ confidence level are stationary.

\section{The results of hypothesis testing}

The research hypothesis suggests that material weaknesses in internal controls have positive effects on future stock price crash risk. The results of the hypothesis testing based on the regression model for research samples are shown in Table 5 .

The results of hypothesis testing in Table 5 indicated that the overall regression model is significant and is a good fit. The low (Prob.) probability level of Z-score, at an acceptable error level for $\beta$ suggests that with a $99 \%$ confidence level, material weakness in internal

\begin{tabular}{|c|c|c|c|c|c|c|c|}
\hline Variable Symbol & Mean & Median & Maximum Value & Minimum Value & Standard Deviation & Skewness & Coefficient of Expansion \\
\hline INVENTORY & $0 / 236$ & $0 / 220$ & $0 / 730$ & $0 / 000$ & $0 / 136$ & $0 / 798$ & $3 / 788$ \\
\hline LOG_MKTV & $11 / 618$ & $11 / 480$ & $15 / 570$ & 9/930 & $0 / 796$ & $1 / 328$ & $452 / 6$ \\
\hline LOG_AGE & $1 / 088$ & $1 / 110$ & $1 / 650$ & $0 / 600$ & $0 / 236$ & $0 / 135$ & $2 / 711$ \\
\hline RET & $34 / 855$ & $14 / 590$ & $820 / 164$ & $-78 / 463$ & $82 / 866$ & $4 / 297$ & $3 / 189$ \\
\hline SIZE & $13 / 068$ & $12 / 979$ & $18 / 492$ & $7 / 101$ & $1 / 428$ & $0 / 394$ & $4 / 503$ \\
\hline LEV & $0 / 085$ & $0 / 051$ & $0 / 971$ & $0 / 000$ & $0 / 106$ & $5 / 010$ & $3 / 167$ \\
\hline ROA & $0 / 109$ & $0 / 098$ & $0 / 631$ & $-0 / 339$ & $0 / 132$ & $0 / 337$ & $4 / 678$ \\
\hline WEAK & \multicolumn{7}{|c|}{ Firms with $51.3 \%$ weaknesses in internal control, firms with no weakness in internal control } \\
\hline RESTRUCTURE & \multicolumn{7}{|c|}{ Firms have restructured $14 \%$, firms have not restructured $86 \%$} \\
\hline SALEGRW & \multicolumn{7}{|c|}{ Firms with below the average industry sales $57.4 \%$, firms with average industry sales $42.6 \%$} \\
\hline LOSS & \multicolumn{7}{|c|}{ Firms with financial loss $12.3 \%$, firms without financial loss $87.7 \%$} \\
\hline RZSCORE & \multicolumn{7}{|c|}{ Firms going bankrupt $48.3 \%$, firms not going bankrupt $51.7 \%$} \\
\hline OPAQUE & \multicolumn{7}{|c|}{ Firms with financial statements opacity $53.7 \%$, firms with transparent financial statements $46.3 \%$} \\
\hline CrashRisk & \multicolumn{7}{|c|}{ Firms with future stock price crash risk in t period $50.7 \%$, firms with no crash risk in t period $49.3 \%$} \\
\hline CrashRisk t-1 & \multicolumn{7}{|c|}{ Firms with future stock price crash risk in the previous year $53.5 \%$, firms with no crash risk in the previous year $46.5 \%$} \\
\hline
\end{tabular}
control has a significant positive effect on future stock price crash 
Citation: Araghi SMRR, Lashgari Z (2017) The Effect of Internal Control Material Weaknesses on Future Stock Price Crash Risk: Evidence from Tehran Stock Exchange (TSE). Int J Account Res 5: 151. doi:10.4172/2472-114X.1000151

Page 4 of 5

\begin{tabular}{|c|c|c|c|}
\hline Variable & Symbol & k Statistic & 0.053 \\
\hline Total Inventory to total assets & INVENTORY & 0.065 \\
\hline Market value of equity & LOG_MKTV & 0.000 \\
\hline Logarithm of firm age & LOG_AGE & 0.061 \\
\hline Average monthly return & RET & 0.177 \\
\hline Firm size & SIZE & 0.063 \\
\hline Leverage & LEV & 0.000 \\
\hline Return on assets & ROA & 0.000 \\
\hline
\end{tabular}

Table 2: Kolmogorov-Smirnov Test Results.

\begin{tabular}{|c|c|c|c|c|c|c|c|}
\hline Variable & $\begin{array}{c}\text { Total Inventory over Total } \\
\text { Assets }\end{array}$ & $\begin{array}{c}\text { Market Value of } \\
\text { Equity }\end{array}$ & $\begin{array}{l}\text { Logarithm of } \\
\text { Firm Age }\end{array}$ & $\begin{array}{c}\text { Average Monthly } \\
\text { Return }\end{array}$ & Firm Size & Leverage & $\begin{array}{c}\text { Return on } \\
\text { Assets }\end{array}$ \\
\hline INVENTORY & 1 & & & & & & \\
\hline LOG_MKTV & ${ }^{* *}-0 / 238$ & 1 & & & & & \\
\hline Sig & $0 / 000$ & & & & & & \\
\hline LOG_AGE & ${ }^{* *} 0 / 213$ & ${ }^{*} 0 / 077$ & 1 & & & & \\
\hline sig & $0 / 000$ & $0 / 046$ & & & & & \\
\hline RET & $-0 / 019$ & ${ }^{* *} 0 / 178$ & $0 / 012$ & 1 & & & \\
\hline sig & $0 / 617$ & $0 / 000$ & $0 / 762$ & & & & \\
\hline SIZE & ${ }^{* *}-0 / 102$ & ${ }^{* *} 0 / 687$ & $0 / 217$ & ${ }^{*} 0 / 077$ & 1 & & \\
\hline sig & $0 / 009$ & $0 / 000$ & $0 / 000$ & $0 / 048$ & & & \\
\hline LEV & $-0 / 018$ & ${ }^{* *}-0 / 199$ & $0 / 006$ & $-/ 008$ & ${ }^{*}-0 / 087$ & 1 & \\
\hline sig & $0 / 646$ & $0 / 000$ & $878 / 0$ & $846 / 0$ & $0 / 025$ & & \\
\hline ROA & ${ }^{* *}-0 / 105$ & ${ }^{* *} 0 / 429$ & $-0 / 056$ & ${ }^{* *} 0 / 329$ & ${ }^{* *} 0 / 173$ & ${ }^{* *}-0 / 222$ & 1 \\
\hline sig & $0 / 006$ & $0 / 000$ & $0 / 146$ & $0 / 000$ & $0 / 000$ & $0 / 000$ & \\
\hline
\end{tabular}

(* and ** Significant with $95 \%$ and $99 \%$ confidence level, respectively).

Table 3: Spearman's Correlation Matrix for the Quantitative Variables.

\begin{tabular}{|c|c|c|}
\hline Variable & Symbol & t Statistic \\
\hline Total inventory to total assets & INVENTORY & $-17 / 289$ \\
\hline Market value of equity & LOG_MKTV & $-23 / 508$ \\
\hline Firm age logarithm & LOG_AGE & $-9 / 993$ \\
\hline Average monthly return & RET & $-23 / 112$ \\
\hline Firm size & SIZE & $-10 / 292$ \\
\hline Leverage & LEV & $-16 / 0000$ \\
\hline Return on assets & ROA & $0 / 0000$ \\
\hline
\end{tabular}

Table 4: Unit Root Test by Augmented Dickey-Fuller Test.

\begin{tabular}{|c|c|c|c|c|}
\hline Variable & Symbol & Coefficient & Score Z & Prob. \\
\hline Future stock price crash risk of the previous year & CHASHRISK t-1 & 0/0001 & $0 / 001$ & $0 / 999$ \\
\hline Internal Control Weakness in the previous year & WEAK $_{t-1}$ & $0 / 755$ & $4 / 098$ & $0 / 000$ \\
\hline Restructuring in the Previous year & RESTRUCTURE $_{t-1}$ & $0 / 552$ & $2 / 111$ & $0 / 034$ \\
\hline Below average industry sales in the previous year & SALEGRW $_{\mathrm{t}-1}$ & $-0 / 611$ & $-3 / 027$ & $0 / 002$ \\
\hline Total inventory to total assets in the previous year & INVENTORY $_{\mathrm{t}-1}$ & $0 / 218$ & $0 / 315$ & $0 / 752$ \\
\hline Market value of equity in the previous year & LOG_MKTV & $0 / 418$ & $2 / 303$ & $0 / 021$ \\
\hline Losses in the previous years & LOSS $_{t-1}$ & $1 / 558$ & $3 / 579$ & $0 / 000$ \\
\hline Altman Bankruptcy Index in the previous year & RZSCORE $_{\mathrm{t}-1}$ & $0 / 619$ & $2 / 690$ & $0 / 007$ \\
\hline Firm age logarithm in the previous year & LOG_AGE $E_{t-1}$ & $0 / 213$ & $0 / 549$ & $0 / 582$ \\
\hline Average monthly return in the previous year & $\mathrm{RET}_{\mathrm{t}-1}$ & $-0 / 0009$ & $-0 / 825$ & $0 / 409$ \\
\hline Firm size in the previous year & $\mathrm{SIZE}_{\mathrm{t}-1}$ & $-0 / 234$ & $-2 / 457$ & $0 / 014$ \\
\hline Leverage in the previous year & $\operatorname{LEV}_{\mathrm{t}-1}$ & $-1 / 844$ & $-2 / 079$ & $0 / 037$ \\
\hline Return on assets in the previous year & $\mathrm{ROA}_{\mathrm{t}-1}$ & $-2 / 538$ & $-2 / 318$ & $0 / 020$ \\
\hline Financial statements opacity in the previous year & OPAQUE $_{t-1}$ & $0 / 692$ & $3 / 931$ & $0 / 000$ \\
\hline Stationarity & C & $-2 / 400$ & $-1 / 387$ & $0 / 165$ \\
\hline \multicolumn{2}{|c|}{$\begin{array}{l}\text { Maximum Likelihood Test (LR Test) } \\
\text { (Prob) Significance Level }\end{array}$} & \multicolumn{3}{|c|}{$\begin{array}{l}156 / 301 \\
(0 / 000)\end{array}$} \\
\hline \multicolumn{2}{|l|}{$\begin{array}{c}\text { HL Statistics } \\
\text { (Prob)Significance level }\end{array}$} & \multicolumn{3}{|c|}{$\begin{array}{l}18 / 268 \\
(0 / 028)\end{array}$} \\
\hline \multicolumn{2}{|l|}{$\begin{array}{l}\text { (Andrews Statistic) } \\
\text { (Prob) Significance level }\end{array}$} & \multicolumn{3}{|c|}{$\begin{array}{l}19 / 610 \\
(0 / 021)\end{array}$} \\
\hline \multicolumn{2}{|l|}{ McFadden R-SQ } & \multicolumn{3}{|c|}{$1 / 069$} \\
\hline
\end{tabular}

Table 5: Hypothesis Test Results. 
Citation: Araghi SMRR, Lashgari Z (2017) The Effect of Internal Control Material Weaknesses on Future Stock Price Crash Risk: Evidence from Tehran Stock Exchange (TSE). Int J Account Res 5: 151. doi:10.4172/2472-114X.1000151

Page 5 of 5

risk. Therefore, with a $95 \%$ confidence level, the model is confirmed. McFadden coefficient of determination indicated that the variables entered into regression were able to interpret $16 \%$ of variations in dependent variables.

\section{Conclusions}

The study investigated the material weaknesses in internal controls and their effect on future stock price crash risk in companies listed on Tehran Stock Exchange, for five years, during 2011-2016. Findings indicated that the above hypothesis is confirmed. The results also indicated that firms with higher material weaknesses in internal controls are more prone to stock price crash risk compared with those with effective internal controls. In fact, material weaknesses in internal controls contribute to hiding bad news by managers, increase the risk of error and distortion, influence the quality of information and financial reporting, prevent the firms from achieving their goals, and these all lead to future stock price crash risk.

Therefore, the need for effective internal controls in business units is evident. Internal controls, if properly designed and implemented, can contribute to the accuracy and efficiency of information systems and improvement of financial reporting quality. The findings of this study are consistent with the findings of Zhou [11] of the same topic.

\section{Following the Results of the Study}

It is recommended that managers take measures to reduce the future stock price crash risk by designing and implementing effective internal controls, and continuous control monitoring.

It is recommended that Tehran Stock Exchange assist managers in the implementation and enforcement of internal control guidelines (Approved in May 2012) by organizing curriculums and seminars on the growth and development of our capital markets. According to the Article 17 of the internal control guidelines, independent auditors are responsible for making comments on the implementation and enforcement of an effective internal control by companies in their audit reports to the General Assembly of Shareholders. Therefore, the implementation and enforcement of internal controls require compliance with relevant standard guidelines. Auditing Organization and Society of SPAs are expected to take the necessary measures to create enforceable standards.

\section{References}

1. Chorafas DN (2007) "Strategic Business Planning for Accountants: Methods Tools and Case Studies, CIMA Publishing is an imprint of Elsevier".

2. Chenhall RH (2003) "Management control systems design within its organizational context: Findings from contingency-based research and directions for the future", Accounting, Organizations and Society 28: 127-168.

3. Ogneva M, Subramanya KR, Raghunandan K (2007) "Internal Control Weakness and Cost of Equity: Evidence from Sox Section 404 Disclosures", Accounting Review 82: 1255-1297.

4. Karagiorgos T, Drogalas G, Christodoulou P, Pazarskis M (2010) "Internal Auditing as an Effective Tool for Corporate Governance", Journal of Business Management 2: 15-23.

5. Spira L, Page M (2003)"Risk management: The reinvention of internal contro and the changing role of internal audit", Accounting, Auditing and Accountability Journal, 16: 640-661.

6. Kothari SP, Susan S, Wysocki PD (2009) “Do Managers Withhold Bad News?", Journal of Accounting Research 47: 241-276.

7. Kim JB, Zhang L (2010) "Does accounting conservatism reduce stock price crash risk?".

8. Hutton AP, Marcus AJ, Tehranian H (2009) "Opaque financial reports, R2, and crash risk", Journal of Financial Economics 94: 67-86.

9. Lee JH, Cho EJ, Choi HJ (2016) "The Effect of Internal Control Weakness on Investment Efficiency” Journal of Applied Business Research (JABR) 32: 649.

10. Lashgari Z, Gawradar A, Bakhshayesh E (2015) “Internal Control Weakness and Accruals Quality in Companies Listed on Tehran Stock Exchange". ProcediaSocial and Behavioral Sciences $11^{\text {th }}$ International Strategic Management Conference 207: 454-461.

11. Zhou J, Jeong-BK, Ira Y (2013) "Material weakness in internal control and stock price crash risk:Evidence from SOX section 404 disclousure".

12. Cheng A, Hogan R, Zhang E (2012) "Cash Flows, Earnings Opacity and Stock Price Crash Risk". Louisiana State University. CAAA Annual Conference. (www.ssrn.com)

13. GeWeili, Sarah McVay (2005) "The Disclosure of Material Weaknesses in Internal Control after the Sarbanes-Oxley Act”, journal of Accounting Horizons 19: $137-158$.

14. Ashbaugh-Skaife $\mathrm{H}$, Collins DW, William R, LaFond, Kinney Jr et al. (2008) "The Effect of Internal Control Deficiencies and Their Remediation on Accrual Quality". Accounting Review I.83: 217-250. 